\title{
A Study On Relation Between Accounting Treatment For Capitalization Of R\&D Expenditure And Earnings Management In The Korean Defense Industry
}

Kyungkook Im, Hankuk University of Foreign Studies, South Korea Chaechang Im, Andong National University, South Korea

\begin{abstract}
Overall, this paper examines and finds the relation between the ratio of accounting treatment for capitalization of research and development expenditure $(R C R \& D)$. The theoretical model derived from panel analysis resource on Korean defense industry information from 2009 to 2014 indicates that the RCR\&D positively affect earnings management direction through a significantly positive relationship. Also, the effect of large defense industry firms' $R C R \& D$ on earnings management direction is higher than that of small ones despite that large defense industry firms have discretionary accruals in (-) direction compared with small ones. In addition, the effect of defense industry firms' $R C R \& D$ on earnings management direction is strong especially in earnings increasing group. Also the change of $R C R \& D$ is positive influence on discretionary accruals. This enforces that RCR\&D can be related with earnings management direction.
\end{abstract}

Keywords: Information Asymmetry; Defense Industry; R\&D Expenditure; Earnings Management

\section{INTRODUCTION}

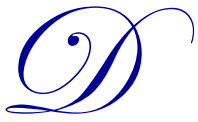

efense industry is an industry related to National Security and Government (the Government of Republic of Korea) and is the key customer of the industry. The asymmetric information between Government and defense industry companies has significant difference in the matter of importance compared to other industries. For example, if a defense industry company does not perform proper internal control on accounting fraud or earnings management behavior occurred in the company, that company will fall under sudden financial difficulty which may cause difficulty in defense activity between defense industry companies and military authorities. It has direct connection to the vacuum of national security.

In general, a system of corporation divides ownership and management, thus as the information asymmetry between stockholders of a corporation and management increases, it is highly likely to occur earnings management behavior (Kim, Bae \& Choi, 2012). Moreover, during Government's regulatory reform period, defense industry companies perform earnings management behavior. It is first, with intent of downward revision in profit in order to hold a lead in negotiation with Government. Second, it is to increase managers' compensation within the boundary of upper and lower limit of management compensation contract, which increases the compensation according to the recorded profit within the boundary of contract (Healy, 1985). Therefore, this study seeks to find an accounting characteristic of a defense industry company, which in that company's management performing earnings management behavior in order to achieve a specific purpose. For this purpose, this study analyses defense industry companies' earnings management behavior focusing on R\&D expenditure, which is typically utilized as a means of earnings management. No. 1038 Intangible Asset of Korean International Financial Reporting Standards regulates recognition requirements for expenditure and asset of $R \& D$ related expenditure. $R \& D$ related expenditure basically treated as an expenditure in accounting and may be treated as asset in case of differentiability, controllability, economic benefit in future are recognizable. Nevertheless, managements utilize R\&D expenditure as a means of earnings management of actually 
accrued profit by capitalizing or treating R\&D expenditure as an expenditure in order to achieve a special purpose (Bae, Yoon \& Kim, 2014). For the defense industry, this type of R\&D investment is affirmatively promoted by Government to defense industry companies. For example, according to Art. 38 of Defense Acquisition Program Act, Government grants a long-term low interest loan to defense industry companies when a defense industry company spends R\&D expenditure to localize defense articles or other military supplies. Government also implements "the support project of weapon system remodeling and development", which supports $75 \%$ of total expense limited to 1 billion won during 3 years when management of weapon system function improvement, an economic ripple effect or feasibility of development plan are recognized. ${ }^{1}$ When management's arbitrariness were intervened, R\&D related expenditure could be the means of earnings management. Thus, this study attempts an analysis whether an accounting treatment of $R \& D$ related expenditure has any relevance with defense industry companies' earnings management.

This study selects discretionary accruals as substitute variable applied for earnings management utilized in analyzing the relevance between capitalizing treatment of defense industry companies' R\&D expenditure and earnings management. This is because management performs earnings management behavior in consideration with accounting estimates or specific accounting treatment, and most of earnings management studies verify earnings management by the volume of discretionary accruals which reflects a net effect of accounting choice (Kwon, Kim, Son, Choi \& Han, 2010).

Previous defense industry-related preceding studies has been performed mostly in analyzing systematic characteristics of cost on defense industry, its drawbacks and determinant of earnings management. This study, however, attaches its importance that it analyzes relevance between earnings management of defense industry companies and accounting treatment of $\mathrm{R} \& \mathrm{D}$ expenditure, where information asymmetry is bigger than other industries.

The plan of this paper is as follows. Section II illustrates preceding studies and elicited hypothesis. Section III discusses research models to verify the hypothesis and the selection of sample companies for empirical testing. Section IV presents the result of empirical testing. Finally, Section V summarizes the result of this study and suggests the limitation this study had.

\section{PRECEDING STUDIES AND ESTABLISHMENT OF HYPOTHESIS}

\subsection{Studies on Earnings Management of Defense Industries}

Defense industry related market has limited demanders like Government, allied nations and other defense industry companies. It also applied to suppliers because Government designates a few companies, i.e., it is an imperfectly competitive market. Thus, the transparency of cost information on defense industry market shows relatively lower than that of civilian market. Accordingly, studies regarding earnings management have been made on the premise that there will is an arbitral accounting treatment performed by management. Yoon, Lee, Jeong and Ahn (2007) argued that the defense industry market has difficulty to apply market principle, and each demander and supplier has exclusive position. They further argued that it makes several characteristics of the market in price determination on product or service and suppliers are tempted to opportunistic earnings management to maximize his/her profit.

Preceding studies related defense industry companies comprise its majority on earnings management due to information asymmetry, which is a native problem between defense industry and Government, its major transaction object. Typically, Lichtenberg (1992) reported defense industry companies in U.S. records higher business profit rates than that of civilian companies. He argued that Government exclusively carry forward the demand and supply follows

\footnotetext{
${ }^{1}$ Defense Acquisition Program Administration (DAPA), implementation of 'the support project of weapon system remodeling and development', Jan. 2, 2014, gukjenews http://www.gukjenews.com/news/articleView.html?idxno=67808 DAPA announced its initiation of 'the support project of weapon system remodeling and development' in 2014 to support company's proposed R\&D for the remodeling of weapon system. Major contents are as follows. First, Governments considers following factors to evaluate the supporting necessity and select support targets: business management of a company's R\&D proposal for the remodeling of weapon system which has domestic procurement record, possibility of domestic necessity as well as feasibility of development plan, technical and economic ripple effect and possibility of export. Government supports interests on R\&D loan or grants a loan on $75 \%$ of total expense limited to 1 billion won during 3 years to selected R\&D according to 'the public announcement on management of financing for the defense industry promotion'. DAPA announced 'this 'supporting project' will activate companies' voluntary investment, and in turn, expect to strengthen R\&D capability and activate performance improvement."
} 
the exclusive market which causes information asymmetry on the quality of defense industry material, which in turn makes the deal price beyond optimum level.

Reichelstein (1992) also stated there is a possibility that defense industry companies may utilize cost accounting information calculated by themselves which Government cannot verify its accuracy and thus could be a mean to secure the profit beyond normal return.

There are several studies analyzing earnings management behavior on the companies transferring the cost which comprises both defense industry and civilian industry, and transferring between them. In particular, Thomas and Tung (1992) discovered an allowance for pension liability employees in non-defense industry has been transferred into employees of defense industry after analyzing first, defense industry contract's cost reimbursement-based profitdecision structure, second, companies' arbitrariness in setting allowance for pension liability which produces both defense articles and non-defense articles.

Kim, Chae and Yang (2007) stated that defense industry companies will intentionally reduce book income to induce the improvement of system preferable to defense industry companies before initiating the improvement of national defense system and reported significant result regarding the statement. Further, Yong, Jeong and Ahn (2015) ${ }^{2}$ performed a study regarding an influence of the independence of board of directors to its earnings management with the number of outside directors as an alternative. The result discovered that higher the independence of board of directors reduced earnings management.

To sum up, defense industry companies excessively appropriate its cost or transfer its cost from civilian industry (department within a company) utilizing information asymmetry due to its inherent transaction structure or reduces its book income to foster preferable condition in negotiation with Government. These various methods were all regarded as earnings management behaviors. According to the analysis of preceding studies, the issue of earnings management on defense industry companies which contains relatively higher information asymmetry compared to civilian companies, requires more detailed study than other industries.

\subsection{Preceding Studies on Accounting Treatment of R\&D Expenditure}

Expensing or capitalization of R\&D expenditure is a typical matter of accounting choice and it has been understood among various scholars that accounting treatment of R\&D expenditure by company is an economic decision-making performance based on company's discretionary choice.

Especially, it is highly probably that $R \& D$ expenditure could be utilized as a means of earnings management pursuant to company's interest in the process of accounting treatment for the expense already expended. $\mathrm{Na}(1999)$ reports that companies having higher level of $\mathrm{R} \& \mathrm{D}$ expenditure and debt ratio with low corporate tax rate prefer capitalization of accounting treatment. On the contrary, companies under the object of regulation prefer expensing of accounting treatment.

Chae and Kim (2000) reported results that first, companies prefer a capitalization of R\&D expenditure for smooth financing. Further, companies with higher tax burden ratio prefer expensing of R\&D expenditure to reduce cost of taxation. Finally, companies choosing expensing of R\&D expenditure with higher R\&D expenditure lead to reduction of net profit and therefore prefer capitalization of accounting treatment.

There were several studies regarding a relevance between unexpected earnings, the difference between expected earnings and actual income, and accounting treatment of R\&D expenditure based on the expectation that a company will treat the accounting by increasing the income when actual income is lower than expected income and reduce the income on the other way. Choi (1997) analyzed whether companies arrange the amount of R\&D investment or decide arbitral accounting treatment on R\&D expenditure in order to achieve certain object by increasing or decreasing the income. The results appears that if companies' income of pertinent year does not meet their expected income, then

\footnotetext{
${ }^{2}$ Yong et al. (2015) stated higher ratio in the number of outside directors in board of directors will lead to reduce earnings management behavior because outside directors, unlike internal directors, monitor and control cost transferring companies which could be an abnormal behavior.
} 
there were strong tendency to increase book income by reducing R\&D investment and capitalizing R\&D expenditure already expensed. On the contrary when the income of pertinent year excesses expected income, then there was a tendency to increase R\&D investment. However, an analysis on the expectation from the reduction of book income by expensing R\&D expenditure already expensed did not deduct significant result. Kim (1996) reported that there was a tendency on companies with higher unexpected income treat accounting treatment of R\&D expenditure as an unexpected R\&D expenditure (period cost).

Meanwhile, studies on relevance between the evaluation of corporate value and accounting treatment of R\&D expenditure has been under active process. Kim and Shin (2006) studied whether there is a particular difference in relevance on corporate value between companies capitalizing total R\&D expenditure, i.e., conservative accounting treatment, and companies which did not. The result reported that R\&D expenditure shows negative relation with corporate value regardless of the difference. Noh (2011) analyzed an influence on corporate value in case of expensing research expenditure and capitalizing regular development cost, dividing into high-tech industry and non-high-tech industry. The result revealed explanation power has increased consistently in both industries and the level of increase of explanation power in high-tech industry was higher than non-high-tech industry. The report further explained the reason with the statement that company spending more $R \& D$ expenditure shows deviation between its book value and market value and as a result tend to show low usability of accounting information. In case of high-tech industry with vigorous $R \& D$ and its relatively low usability of accounting information, their corporate value relatedness was increased by capitalization of R\&D expenditure than that of non-high-tech industry. ${ }^{3}$

To sum up, due to an accounting choice of E\&D expenditure, an accounting treatment of R\&D expenditure may be utilized as an adjusting means of company's book income. Like in earnings management, there are several source of book income adjustment like debt covenant hypothesis, deferral of corporate tax.

\subsection{Setting Up Hypothesis}

An accounting treatment of R\&D expenditure chose by management's voluntary decision making, and it is highly probable this decision making will be utilized as a means of earnings management pursuant to company's business situation. In particular, defense industry spends more R\&D expenditure than that of civilian industry, and thus it is highly probable that $R \& D$ expenditure could be utilized as a means of earnings management. According to Art. 11 of Defense Acquisition Program Act (No. 13507), it regulates localization and R\&D of weapon system in order to achieve independent national defense capability through the development of defense science and technology under the basic performance principle of improvement business on defense capacity. Article 38 specifies that Government may grant a long-term low interest loan to defense industry companies when a defense industry company spends $R \& D$ expenditure to localize defense articles or other military supplies. Defense industry companies will spend more R\&D expenditure than civilian industry as far as Government supports sufficient funds of R\&D activities. Therefore, this study tries to reveal an accounting treatment of $\mathrm{R} \& \mathrm{C}$ expenditure is utilized as a means of earnings management by verifying the relation between the tendency of accounting treatment on R\&D expenditure in the defense industry which records higher information asymmetry and discretionary accruals as an alternative to earnings management. For this purpose, we set following hypotheses.

Hypothesis 1: in defense industry, the level of capitalizing accounting treatment of R\&D expenditure has positive relation with discretionary accruals.

In addition, we will analyze the difference of relevance between capitalizing account treatment of R\&D expenditure per corporate size and earnings management. First, we expect there will be a different level of asymmetry per corporate size. Generally, Government applies stricter regulation and monitoring on conglomerates than small and mediumsized entities (SMEs). Thus, conglomerates will show lower level of earnings management than SMEs, and so does on the level of earnings management through accounting treatment of R\&D expenditure. Accordingly, we set following hypothesis.

\footnotetext{
${ }^{3} \mathrm{R} \& D$ expenditure reduces utility of accounting information, but capitalizing R\&D expenditure formerly treated expense rises value relevance and eventually increases utility of accounting information (Lev \& Zarowin, 1999: Chambers et al, 2003)
} 
Hypothesis 2-1: a larger defense industry company has lower discretionary accruals.

Hypothesis 2-2: in defense industry, the influence of conglomerates' level of capitalizing accounting treatment on R\&D expenditure will be less than that of SMEs.

However, we may consider "Hypothesis 2-2" in opposite. Park and Yang. (2011) shows there are a difference of level of R\&D expenditure intensity between conglomerates and SMEs. SMEs records higher than conglomerates and SMEs has more burden on outside monitoring on single $R \& D$ expenditure item. Thus, conglomerates may have lower discretionary accruals but higher relevance between a ratio of capitalizing accounting treatment on R\&D expenditure and earnings management. Therefore, we set following hypothesis.

Hypothesis 3: in defense industry, the influence of level of capitalizing accounting treatment on R\&D expenditure to discretionary accruals that affects conglomerates is higher than that of SMEs.

\section{A STUDY DESIGN AND SAMPLE SET UP}

\subsection{An Estimation of Discretionary Accruals}

This study estimated discretionary accruals according to modified-Jones model (Dechow, Sloan \& Sweeny, 1995). Specifically, we estimate discretionary accruals by formula (1) and (2), and in turn, analyze the influence of accounting treatment of R\&D expenditure on discretionary accruals.

Formula (1)

$$
\frac{T A_{i t}}{\text { Asset }_{i t-1}}=a_{0}+\left(\frac{1}{\text { Asset }_{i t-1}}\right)+\beta_{1}\left(\frac{\Delta R E V_{. i t}-\Delta A R_{\text {.tt }}}{\text { Asset }_{i t-1}}\right)+\beta_{2}\left(\frac{P P E_{\text {.t }}}{\text { Asset }_{i t-1}}\right)+\xi_{t}
$$

Formula (2)

$$
D A=\frac{T A}{\text { Asset }_{i t-1}}-\left[a_{0}\left(\frac{1}{\text { Asset }_{i t-1}}\right)+\beta_{1}\left(\frac{\Delta R E V_{. i t}-\Delta A R_{. i t}}{\text { Asset }_{i t-1}}\right)+\beta_{2}\left(\frac{P P E_{. i t}}{\text { Asset }_{i t-1}}\right)\right]
$$

$T A_{i t} \quad$ Corporate $\mathrm{j}$ 's total accruals in year $\mathrm{t}($ net income - cash from operations)

$\triangle R E V_{i t} \quad$ Corporate j's difference in sales (current sales - previous sales)

$\triangle A R_{i t} \quad$ Corporate j's difference in account receivables in year $\mathrm{t}$ (current account receivables previous account receivables)

$P P E_{i t} \quad$ Corporate $\mathrm{j}$ ' tangible assets in year $\mathrm{t}$

Asset $_{i t-1}$ Corporate j's total assets in year t-1

\subsection{Empirical Analysis Model}

In this study, an $R \& D$ expenditure treated (in accounting) as a capitalization is an increased development expenditure of the financial statement of the year. An R\&D expenditure treated as an expensing is a sum of regular development expense, research expense and ordinary research and development expense in all-inclusive income statements.

This study premises management intervenes with its discretionary decision making in deciding accounting treatment of $R \& D$ expenditure. The ratio of capitalized among total accrued R\&D expenditure (Arnd), formula (3), is as follows.

Formula (3)

$$
\text { Arndportin }=\frac{\text { RDexpendituretreatedasanasset }^{1)}}{\text { totalaccruedRDexpenditure }^{2)}}
$$


1) $R \& D$ expenditure treated as an asset:

2) Total accrued R\&D expenditure:

*R\&D expenditure treated as an expenditure
Statement of financial position year end R\&D expenditure - basic development expenditure + Depreciated amount of development expenditure at the term

$R \& D$ expenditure treated as an asset $+R \& D$ expenditure treated as an expenditure

$=$ Research expenditure in all-inclusive income statements + regular development expenditure, regular R\&D expenditure

A model to verify this study's hypotheses are as follows in formula (4).

Formula (4)

$$
\begin{gathered}
D A_{. i t}=a_{0}+\beta_{1} \text { Arnd }_{. t}+\beta_{2} \text { Big }_{. i t}+\beta_{3} \text { Big }_{. i t} \times \text { Arnd }_{. i t}+\beta_{4} R O A_{. i t}+\beta_{5} T A_{i t-1}+\beta_{6} L E V_{i t} \\
+\beta_{i} \sum \text { Firm }_{i}+\beta_{i} \sum \text { Year }_{h}+\xi_{i t}
\end{gathered}
$$

$\begin{array}{ll}\operatorname{Arnd}_{i t} & : \text { Corporate j's ratio of capitalized R\&D expenditure in year } \mathrm{t} \\ \text { Big }_{i t} & : \text { Dummy variables, } 1 \text { for conglomerate, } 0 \text { for not conglomerate } \\ \text { Big }_{i t} \times \text { Arnd }_{i t} & : \text { Moderating variable } \\ \operatorname{ROA}_{i t} & : \text { Corporate } \mathrm{j} \text { 's return on total assets in year } \mathrm{t} \\ \operatorname{TA}_{i t-1} & : \text { Corporate } \mathrm{j} \text { 's total accruals in year } \mathrm{t}-1 \\ \mathrm{LEV}_{i t} & : \text { Corporate } \mathrm{j} \text { 's debt ratio in year } \mathrm{t} \\ \sum \text { Firm }_{i} & : \text { Corporate dummy } \\ \sum \text { Year }_{i} & : \text { Year dummy }\end{array}$

The model's dependent variable is discretionary accruals of an entire company. As explained earlier in Formula (3), this study set the ratio of capitalized R\&D expenditure in the year as an explanatory variable to prove Hypothesis 1 that confirming whether the level of capitalizing R\&D expenditure is a signal of discretionary accruals. An explanatory variable to verify Hypothesis 2-1 that confirming the difference in earnings management between conglomerates and SMEs, this study set " 1 " for conglomerates and "0" for not conglomerates. Also, a moderating variable was set to multiply the ratio of capitalized R\&D expenditure and a dummy variable to confirm Hypothesis 2-2 that whether being a conglomerate has a regulation effect in signing discretionary accruals of $R \& D$ expenditure.

This study also set return on total assets, total accruals in the former half (of the year) and debt ratio a control variables. We included return on total assets to control management performance pursuant to a corporate size. Total accruals in the former half (of the year) was included based on the study of Becker, Defond, Jiambalvo, and Subranmanyam. (1998) that it affects discretionary accruals of the term and has negative correlation. Further, debt ratio was included relying on the study of DeFond and Jiambalvo (1994) that higher debt ratio causes elevating probability to violate a debt covenant. 


\subsection{Sample Selection}

The current status of defense industry companies in this study, we utilized current status of members ${ }^{4}$ provided by Korea Defense Institute Association website. Moreover, we collected companies' financial materials utilizing KISVALUE (ver. 3.2) of Korea Investors Service Inc. between 2009 and 2014. Among entire 476 observed values, we excluded missing values, values less than 0 and cash from operation is missing values. Therefore, we finally chose and utilized 464 observed values. ${ }^{5}$

\section{RESULTS OF EMPIRICAL TESTING}

\subsection{Descriptive Statistics and Correlation Analysis}

Table 1 indicates descriptive statistics of 464 samples of study objects between 2009 and 2014. An average value of DA records -0.001 , a negative value. However, the standard deviation recorded 0.111 which we may estimate that it shows comparatively equal distribution both in positive and negative numbers. We found that $T A_{i t-1}$ mainly generated negative total accruals, as an average of -0.028 and the median of -0.020 . Arnd $d_{i t}$ shows an average of 0.504 and the standard deviation is bigger than the average. $B i g_{i t}$ has an average of 0.288 , which shows the weight of conglomerates in entire defense industry is lower than that of SMEs, and thus Korean defense industry is comprised of SMEs mainly.

Table 1. Descriptive Statistics

\begin{tabular}{|c|c|c|c|c|c|}
\hline Variables & Average & Median & $\begin{array}{l}\text { Standard } \\
\text { deviation }\end{array}$ & Minimum value & Maximum value \\
\hline$D A_{i t}$ & -0.001 & 0.003 & 0.111 & -0.588 & 0.797 \\
\hline Arnd $_{i t}$ & 0.504 & 0.580 & 0.595 & -3.273 & 3.543 \\
\hline Big $_{i t}$ & 0.288 & 0.000 & 0.453 & 0.000 & 1.000 \\
\hline Big $_{i t}+$ Arnd $_{i t}$ & 0.110 & 0.000 & 0.288 & -0.904 & 1.405 \\
\hline$R O A_{i t}$ & 0.026 & 0.030 & 0.094 & -0.768 & 0.401 \\
\hline$T A_{i t-1}$ & -0.028 & -0.021 & 0.115 & -1.043 & 0.283 \\
\hline$L E V_{i t}$ & 0.620 & 0.623 & 0.262 & 0.093 & 2.219 \\
\hline
\end{tabular}

Table 2 shows a correlation of variables utilized in hypotheses. $D A_{i t}$ has significant correlation with $A r n d_{i t}$ which records 0.089 , it shows higher capitalization of R\&D expenditure leads to increase discretionary accruals. Arnd $d_{i t}$ has correlation with $\mathrm{Big}_{i t}$, which records -0.184. it shows significant correlation and conglomerates has lower level of capitalization of R\&D expenditure compared to SMEs, it is also expected that an influence to discretionary accruals will be less than that of SMEs. $R O A_{i t}$, a control variable, has positive effect, and negative effect with $L E V_{i t}$.

\footnotetext{
${ }^{4}$ According to Art. 35 of Defense Acquisition Program Act, total 95 domestic companies are designated as a defense industry company companies which are10 thermal powers (Hanwha Defense Systems, etc.), 9 ammunitions (Poongsan, etc.), 14 mobility (Doosan Heavy Industries \& Construction, etc.), 16 aircraft guidance (Korea Aerospace Industries, etc.), 19 communication electronics (Hanwha Systems, etc.), 3 CBR (chemical, biological, and radiological, Sancheong, etc), 13 others (Dongin optical science, etc).

${ }^{5}$ In modified-Jones model (1995), it calculates total accruals by deducting cash flow of operation from sales in the term. This study excluded it because if the cash flow of operation is missing, total accruals are excessively calculated and eventually affects an estimation of coefficient for discretionary accruals.
} 
Table 2. Pearson Correlation Coefficient of Variables on Hypothesis

\begin{tabular}{|c|c|c|c|c|c|c|c|}
\hline Division & $D A_{i t}$ & Arnd $_{i t}$ & $B_{i t}$ & $\begin{array}{c}\text { Big }_{i t} \\
+ \text { Arnd }_{i t}\end{array}$ & $R O A_{i t}$ & $T A_{i t-1}$ & $L E V_{i t}$ \\
\hline$D A_{i t}$ & 1.000 & & & & & & \\
\hline Arnd $_{i t}$ & $\begin{array}{l}0.089 \\
0.099\end{array}$ & 1.000 & & & & & \\
\hline$B i g_{i t}$ & $\begin{array}{l}0.044 \\
0.361\end{array}$ & $\begin{array}{r}-0.184 \\
0.001\end{array}$ & 1.000 & & & & \\
\hline Big $_{i t}+$ Arnd $_{i t}$ & $\begin{array}{l}0.070 \\
0.191\end{array}$ & $\begin{array}{l}0.229 \\
<.0001\end{array}$ & $\begin{array}{l}0.559 \\
<.0001\end{array}$ & 1.000 & & & \\
\hline$R O A_{i t}$ & $\begin{array}{l}0.509 \\
<.0001\end{array}$ & $\begin{array}{l}0.087 \\
0.102\end{array}$ & $\begin{array}{l}0.013 \\
0.781\end{array}$ & $\begin{array}{l}0.045 \\
0.403\end{array}$ & 1.000 & & \\
\hline$T A_{i t-1}$ & $\begin{array}{r}-0.059 \\
0.215\end{array}$ & $\begin{array}{l}0.044 \\
0.413\end{array}$ & $\begin{array}{l}0.050 \\
0.287\end{array}$ & $\begin{array}{l}0.102 \\
0.055\end{array}$ & $\begin{array}{r}-0.024 \\
0.605\end{array}$ & 1.000 & \\
\hline$L E V_{i t}$ & $\begin{array}{r}-0.022 \\
0.640\end{array}$ & $\begin{array}{r}-0.014 \\
0.789\end{array}$ & $\begin{array}{l}0.001 \\
0.989 \\
\end{array}$ & $\begin{array}{r}-0.015 \\
0.773\end{array}$ & $\begin{array}{c}-0.193 \\
<.0001\end{array}$ & $\begin{array}{r}-0.142 \\
0.002\end{array}$ & 1.000 \\
\hline
\end{tabular}

\subsection{The Result of Empirical Analysis}

The Table 3 is the result of empirical analysis. We divided entire samples into one party that records increased net income year-on-year and another that decreased. Then, we analyzed the influence of each party's accounting treatment of R\&D expenditure on earnings management. This process was to figure out whether the accounting treatment of R\&D expenditure was a means to manipulate increase or decrease of net income. In each model, explanatory variables are the ratio of capitalized R\&D expenditure, whether conglomerate or not and conglomerate's adjustment effect of capitalization. ${ }^{6}$ Panel A is the result analysis on entire 464 samples. A regression coefficient of Arnd $_{i t}$, the ratio of capitalization on discretionary accruals, is 0.0260 and $t$ stat records 2.03 which shows explanation power at $5 \%$ level. It implies that higher capitalization rate of $\mathrm{R} \& \mathrm{D}$ expenditure leads to higher adjustment of profit and it supports Hypothesis 1 . We parameterized based on the ratio of capitalizing R\&D expenditure, we may inversely interpret in case when R\&D expenditure was expensed. i.e., if R\&D expenditure was expensed, then it influences on decrease of book income with the same level of explanation power.

Next, a regression coefficient of $B i g_{i t}$, the dummy variable indicating whether it is a conglomerate, is -0.1011 and $\mathrm{t}$ stat records -1.95 which shows explanation power at $10 \%$ level. i.e., conglomerate has lower level of upward adjustment in its income than that of SMEs, and it supports Hypothesis 2-1. Further, a regression coefficient of Big ${ }_{i t}+$ Arnd $_{i t}$ to confirm whether conglomerate's level of capitalizing R\&D expenditure adjusts earnings management upwardly, is 0.0774 and $t$ stat records 2.10 which shows explanation power at $5 \%$ level. Thus, conglomerate shows higher ratio of capitalizing R\&D expenditure leads to more upward adjustment of earnings management than SMEs. Moreover, $T A_{i t-1}$ as a control variable on discretionary accruals of defense industry companies during the period is each 0.8207 and -0.1824 which shows explanation power at $1 \%$ level. It matches with the study of Becker et al. (1998). Shows identical with the study of DeFond and Jiambalvo (1994) which both appear negative value but it was not a significant result statistically.

\footnotetext{
${ }^{6}$ As an effect of verification through moderating variables, we analyze the different influence of capitalization on earnings management between conglomerates and SMEs.
} 
Table 3. Regression of Hypothesis (on entire samples)

\begin{tabular}{|c|c|c|c|}
\hline \multicolumn{4}{|l|}{ Panel A. 464} \\
\hline \multicolumn{4}{|c|}{$D A_{. i t}=a_{0}+\beta_{1}$ Arnd $_{. i t}+\beta_{2}$ Big $_{. i t}+\beta_{3}$ Big $_{. i t} \times$ Arnd $_{. i t}+\beta_{4} R O A_{. i t}+\beta_{5} T A_{i t-1}+\beta_{6} L E V_{i t}+\beta_{i} \sum$ Firm $_{i}+\beta_{i} \sum$ Year $_{h}+\xi_{i t}$} \\
\hline \multirow{2}{*}{ Variable } & \multicolumn{3}{|c|}{ Dependent Variable: } \\
\hline & Predicted sign & Estimate & t-value \\
\hline Intercept & $?$ & 0.0137 & 0.33 \\
\hline $\operatorname{Arnd}_{i t}$ & + & $0.0260^{* *}$ & 2.03 \\
\hline$B i g_{i t}$ & - & -0.1010 & -1.95 \\
\hline$B_{i g}+$ Arnd $_{i t}$ & $?$ & $0.0774^{* *}$ & 2.10 \\
\hline$R O A_{i t}$ & + & $0.8207^{* * *}$ & 12.63 \\
\hline$T A_{i t-1}$ & - & $-0.1824^{* * *}$ & -3.92 \\
\hline$L E V_{i t}$ & - & -0.0274 & -0.82 \\
\hline Firm Fixed/Time Fixed & \multicolumn{3}{|c|}{ Included } \\
\hline Adjusted- & & 0.4370 & \\
\hline
\end{tabular}

Table 4 shows the result of influence of capitalizing R\&D expenditure on earnings management among groups which has fluctuated its net income year-on-year.

Panel B where their net income has increased year-on-year, an regression coefficient of $\operatorname{Arnd}_{i t}$, a ratio of capitalization on discretionary accruals, is 0.04227 and $\mathrm{t}$ stat records 1.87 , which shows still significant explanatory power at $10 \%$ level. On the contrary, a regression coefficient of Arnd $_{i t}$ in panel $\mathrm{C}$ does not have significant explanatory power. We may analyze this result that a company recorded low net income in previous year has strong tendency to improve its net income compared to company recorded higher net income in previous year and thus adjust its book income upwardly by capitalizing $R \& D$ expenditure. 
Table 4. Regression of Hypothesis (groups net income fluctuated)

\begin{tabular}{|c|c|c|c|}
\hline \multicolumn{4}{|c|}{ Panel B. (groups increased its net income year-on-year): 196} \\
\hline \multicolumn{4}{|c|}{$D A_{. i t}=a_{0}+\beta_{1} A_{r n d}{ }_{i t}+\beta_{2}$ Big $_{. i t}+\beta_{3}$ Big $_{. i t} \times$ Arnd $_{. i t}+\beta_{4} R O A_{. i t}+\beta_{5} T A_{i t-1}+\beta_{6} L E V_{i t}+\beta_{i} \sum$ Firm $_{i}+\beta_{i} \sum$ Year $_{h}+\xi_{i t}$} \\
\hline \multirow{2}{*}{ Variable } & \multicolumn{3}{|c|}{ Dependent Variable: } \\
\hline & Predicted sign & Estimate & t-value \\
\hline Intercept & $?$ & 0.0310 & 0.53 \\
\hline $\operatorname{Arnd}_{i t}$ & + & $0.0423^{* *}$ & 1.87 \\
\hline$B i g_{i t}$ & - & -0.0257 & -0.30 \\
\hline Big $_{i t}+$ Arnd $_{i t}$ & $?$ & 0.0286 & 0.58 \\
\hline$R O A_{i t}$ & + & $1.2069^{* * *}$ & 5.19 \\
\hline$T A_{i t-1}$ & - & $-0.1919^{* * *}$ & -2.61 \\
\hline$L E V_{i t}$ & - & $-0.1124^{* * *}$ & -2.27 \\
\hline Firm Fixed / Time Fixed & \multicolumn{3}{|c|}{ Included } \\
\hline Adjusted- & & 0.4606 & \\
\hline
\end{tabular}

Panel C. (groups decreased its net income year-on-year): 268

\begin{tabular}{|c|c|c|c|}
\hline \multirow{2}{*}{ Variable } & \multicolumn{3}{|c|}{ Dependent Variable: } \\
\hline & Predicted sign & Estimate & t-value \\
\hline Intercept & $?$ & 0.0229 & 0.37 \\
\hline Arnd $_{i t}$ & + & 0.0263 & 1.47 \\
\hline $\mathrm{Big}_{i t}$ & - & -0.1089 & -1.54 \\
\hline $\operatorname{Big}_{i t}+$ Arnd $_{i t}$ & $?$ & 0.0981 & 1.28 \\
\hline$R O A_{i t}$ & + & 0.8288 & 9.24 \\
\hline$T A_{i t-1}$ & - & -0.1457 & -1.75 \\
\hline$L E V_{i t}$ & - & -0.0610 & -0.92 \\
\hline Firm Fixed / Time Fixed & \multicolumn{3}{|c|}{ Included } \\
\hline Adjusted- & \multicolumn{3}{|c|}{0.4512} \\
\hline
\end{tabular}

\subsection{Additional Analysis}

Additionally, we verified whether we could observe earnings management pursuant to a ratio fluctuation of capitalizing R\&D expenditure year-on-year. On the basis of Formula (4) and analysis of Table 5, if a ratio has increased, we may estimate upward adjustment of profit. A primary purpose of additional analysis is to confirm the intent of earnings management including a ratio fluctuation of capitalizing R\&D expenditure. Thus, we set a level variable of discretionary accruals as a dependent variable and a ratio of capitalizing $R \& D$ expenditure, a primary explanatory variable, as a varying variable. $\Delta A r n d_{i t}$ is the difference of capitalizing ratio between $\mathrm{t}$ and $\mathrm{t}-1$, and it is a continuous variable. If a company with increased capitalizing $R \& D$ expenditure ratio year-on-year also records increased discretionary accruals, it will bolster previous analysis results.

A regression coefficient of $\Delta A r n d_{i t}$ affecting discretionary accruals is 2.63 , which shows positive and significant explanatory power at $1 \%$ level. This result implies that a company which records increased ratio of capitalizing R\&D expenditure has high probability to report its profit upward in the term. Control variables are similar with previous analyses. 
Table 5. Regression analysis based on variation of capitalization ratio

\begin{tabular}{|c|c|c|c|}
\hline \multicolumn{4}{|c|}{$D A_{i t}=a_{0}+\beta_{1}+\Delta$ Arnd $_{i t}+\beta_{2} R O A+\beta_{3} T A_{i t-1}+\beta_{4} L E V_{i t}+\beta_{i} \sum$ Firm $_{i}+\beta_{h} \sum$ Year $_{h}+\xi_{i t}$} \\
\hline \multirow{2}{*}{ Variable } & \multicolumn{3}{|c|}{ Dependent Variable: } \\
\hline & Predicted sign & Estimate & t-value \\
\hline Intercept & $?$ & -0.0735 & -1.50 \\
\hline$\Delta$ Arnd $_{i t}$ & + & $0.0249^{* * *}$ & 2.63 \\
\hline$R O A_{i t}$ & + & 0.9058 & 13.55 \\
\hline$T A_{i t-1}$ & - & -0.1317 & -2.69 \\
\hline$L E V_{i t}$ & + & -0.0234 & -0.65 \\
\hline Firm Fixed/Time Fixed & \multicolumn{3}{|c|}{ Included } \\
\hline
\end{tabular}

\section{CONCLUSION}

\subsection{A Study on Defense Industry's Earnings Management}

The purpose of this study is to analyze whether a capitalization of R\&D expenditure has relevance with earnings management in defense industry. In addition, we divided two groups into one that increased net income and another records decreased. Then, we proceeded whether a capitalization of R\&D expenditure influences on earnings management. Further, we analyzed an increased ratio of capitalizing R\&D expenditure year-on-year influences on upward adjustment of profit.

The analysis period of this study was between 2009 and 2014 which we were able to collect data based on a business analysis data of defense industry companies, then we measured a capitalization ratio (Arndit) among 464 samples. We utilized a discretionary analysis $\left(D A_{i t}\right)$ estimated by modified-Jones model $(1995)$ as a proxy measure of earnings management. Major results are as follows.

First, relatively higher ratio of capitalizing R\&D expenditure recorded higher significant relation with discretionary accruals. Second, a capitalizing ratio of R\&D expenditure had positive effect to discretionary accruals. Third, when net income has increased year-on-year, a capitalizing ratio of $R \& D$ expenditure had significant and positive effect to discretionary accruals. Fourth, when a capitalizing ratio of R\&D expenditure has increased year-on-year, the level of earnings management has increased as well.

This study has its meaning, from earnings management point, to practically analyze and approach an accounting treatment of execution of R\&D expenditure in which Government aggressively support to localize its materials. Further, according to Art. 28 of enforcement regulation, No. 666 of Ministry of National Defense decree regarding cost accounting of defense articles, regulates a defense industry company, a counterparty of the contract, to submit evidential materials for the calculation of cost so to verify a feasibility of the cost. However, it is difficult for Government to scrutinize earnings management of defense industry companies where information asymmetry is high. At this point, analyses of this study regarding earnings management pursuant to conglomerates and SMEs, increase and decrease of net income and capitalizing ratio of $\mathrm{R} \& \mathrm{D}$ expenditure will be a good guideline on earnings management of defense industry companies.

\section{REFERENCES}

Bae J., Yoon, J., \& Kim, S. (2014). Earnings management through research and development accounting: An emphasis on corporate life cycle. Yonsei Business Review, 51(1), 71-98.

Becker, C., Defond, M., Jiambalvo, J., \& Subranmanyam, K. (1998). The effect of audit quality on earnings management. Contemporary Accounting Research, 15,1-24.

Chae, J \& Kim, J. (2000). A study on the choice of accounting treatment for R\&D costs determinant factor. The Korean Tax and Accounting Journal, 7(0), 403-429.

Chambers, D., Jennings, R. \& Thompson, R. (2003). Managerial discretion and accounting for research and development costs. Journal of Accounting, Auditing \& Finance, 18, 35-79.

Choi, K. (1997). Earnings management through the R\&D investment decision and choice of accounting methods for R\&D costs. The Korean Tax and Accounting Journal, 4(0), 263-546. 
Dechow, P., Sloan, R., \& Sweeney, A. (1995). Detecting earnings management. The Accounting Review, 70(2), $193-225$.

Defense Acquisition Program Act No. 13507 in Korea, (2015). Art. 28 of Enforcement Regulation, No. 666 of Ministry of National Defense Decree, 2008.

DeFond, M., \& Jiambalvo, J. (1994). Debt covenant violation and manipulation of accruals. Journal of Accounting and Economics, 17, 145-176.

Healy, P. M. (1985). The effect of bonus schemes on accounting decisions. Journal of Accounting and Economics, 7, 85-107.

Kim J., Bae J. \& Choi E. (2012). A study on the effects to real earnings management caused by information asymmetry between CEO and interested parties. Korean Journal of Management Accounting Research, 12(1), 63-88.

Kim Y., Chae. M., \& Yang. D, (2007). A study on the effects of defense industry characteristics on the earnings management. Korean Accounting Information Research, 25(4), 221 251.

Kim. S. (1996). The effect of consideration of reporting Income on R \&D. Korean Accounting Information Research, 7(10), 19 32.

Kim, Y. \& Shin, K., (2006). The effect of alternative accounting policy for the R\&D of the KOSDAQ venture firms on the value relevance of R\&D. The Korean Small Business Studies, 28(2), 157-180.

Lev, B. \& Zarowin, T. (1999). The boundaries of financial reporting and how to extend them. Journal of Accounting Research, Autumn, 353-385.

Lichtenberg. F. R. (1992). A perspective on accounting for defense contracts. The Accounting Review, 67(4), 741-752.

$\mathrm{Na}$, I. (1999). An empirical study on the determinants of R\&D accounting choice. Economic Research, 20(1), 181-202.

Noh, H., (2011). A research on the value relevance of R\&D Expenses - The emphasis on endogenous growth theory. Journal of Taxation and Accounting, 12(1), 9-43

Park, Y. \& Yang, D. (2011). An empirical study on the relationship among R\&D, other intangible investment and firm `s performances. Advancing Small Enterprise Innovation Research, 14(1), 27-46

Reichelstein, S. (1992). Constructing incentive schemes for government contracts: An application of agency theory. The Accounting Review, 67(4), 712-731.

Thomas, J. K. \& Tung, S. (1992). Cost manipulation incentives under cost reimbursement: Pension costs for defense contracts. The Accounting Review, 67(4), 691-711.

Yong, H., Jeong H., Ahn, T., \& Park. J. (2015). Cost shifting activities in the Korean Defense Industry and their determinants. Korean Accounting Journal, 24(6), 133-158.

Yoon, S., Lee, W., Jeong, H. \& Ahn. T. (2007). Does Korean Defense Industry manage earnings? Korean Accounting Review, 32(1), 59-88. 